\title{
ANALYSIS THE USE OF INSTRUCTIONAL MEDIA ON TEACHING ENGLISH TO YOUNG LEARNER AT ELEMENTARY SCHOOL IN BANDUNG
}

\author{
Resti $^{1}$, Cynantia Rachmijati ${ }^{2}$ \\ ${ }^{1}$ IKIP Siliwangi \\ ${ }^{2}$ IKIP Siliwangi \\ ${ }^{1}$ restisa@student.ikipsiliwangi.ac.id, ${ }^{2}$ cynantia@yandex.com
}

\begin{abstract}
Instructional media is a tool used by teachers to explain material in the classroom, which is anything that can be used to stimulate children's thoughts, attention, and feelings, to encourage the learning process. Therefore the teacher of English for young learner must create a fun classroom setting by using media, beside of technique and method to attract students attention. This Research was conducted at elementary school in Bandung, West Java. The participants in this study were 30 grade 3 elementary school students and an English teacher. The aimed of this study is to describe the teacher's preparation and explain the use of media in the classroom. This study uses descriptive qualitative methods, by collecting data using interviews, observation, and document analysis. The results of this study indicate that in preparing the media, the teacher must understand the material to be taught and adjust the media to be used with the material. On this research the media used by teachers are coursebooks, video, realia and picture. Such as video to train on students' speaking and listening skills. Picture is to increase children's knowledge about vocabulary. Coursebooks are used to practice student's reading and writing skill, while realia is used to introduce children to real subject.
\end{abstract}

Keywords: English, Young learner, Instructional Media

\section{INTRODUCTION}

The teacher uses instructional media when teaching process, the shape of media is varies according to the needs of the teacher in class. The definition of instructional media itself is a tool used by teachers to explain material in the classroom, which is anything that can be used to stimulate children's thoughts, attention, and feelings, to encourage the learning process. In line with Puyada, Ganefri, Ambiyar, Wulansari, \& Hayadi, (2018) says that instructional media is any form of learning means that can be used in a learning process that aims to enhance effectiveness and efficiency in achieving a learning objective. Besides that, to achieve the learning objectives, the teacher must choose media, method, the technique that is appropriate to the characteristics of students, especially in elementary school, so the class becomes fun and does not get bored quickly. Furthermore, Puyada et al. (2018) say that English teachers of young learner classes must be able to equip the class with resource which are interesting and user friendly so the teacher will be able to help students to learn English better.

Related to the importance of instructional media, According to Farida, Isrina, \& Apsari (2019) the teacher must have a creative idea in choosing the media to be used in teaching. There are many media that can be used by teachers during the learning process such as, book, picture, song, and others. Kasbolah as cited in Zamzami (2019) divided media in three kind (1) Audio media, is media that can only be heard by the ear without being seen, such as CDs, songs and others. (2) Visual media is media that can be seen by the eye, such as pictures, books, realia, flashcards. 
(3) Audiovisual media is media that can be seen and can be heard like video. All of these media can be used by the teacher following the needs and learning objectives. According to Syathroh, Musthafa \& Purnawarman (2019), the instructional media can be presented textual, animation, videos, and picture. The combination of presentation is expected to learners more motivated and not quickly bored.

The use of media can help the teacher delivering English material in elementary schools Easier. Such as make learning activities more fun, effective and attract the attention of students. Relevant with Sanaky (2009) as cited in Puspitarini \& Hanif (2019) instructional media give several benefits as follows: (1) by using learning media, the learning process will be more interesting, (2) can clarify learning materials, so that student can easily understand the material and enable student to master the learning objectives (3) using instructional media the learning process more varied, not only orally but can also immediately see, and listening the media (4) students listening to the material presented by the teacher, doing more learning activities such as: observing, doing, demonstrating, and others. With many benefits gained, the teacher will be helped in conveying English material.

English as a Foreign Language in Indonesia put into local content in elementary schools. The English instruction in Elementary school is intended to endorse the mastery and develovepment of the four basic abilities and skills, that is reading, listening, pronouncing and writing as reflected in abilities (Lisa, 2019). In addition, Piaget as cited in Saud \& Rahman (2019) elucidates that elementary school students passing through the stage of thinking concretely, requiring many illustrations, models, pictures, and other activities. It means the English teacher must use a variety of ways, techniques or media to adapt to the student's needs while studying to achieves the goals of learning. Based on observation in elementary school in Cimahi, teaching English in elementary schools is not easy and certainly different from teaching in junior or senior high school. This is caused by characteristics of young learner are different with other learners. In addition, the teacher must create a pleasant classroom atmosphere, for example by using instructional media.

Pinter (2011) as cited in Utami, Fauziati, \& Rochsantiningsih (2019) categorized young learners into three groups of age: (1) preschool, (2) primary school years, and (3) early adolescents. Preschool are children 3-5 years old, primary school years are children 6-12 yearsold, and early adolescents is when a student has left elementary school. Meanwhile, Cahyati, Parmawati, \& Atmawidjaja (2019) mention the most important characteristic of a young learner is their tendency to be active, the teachers must pay attention to which children are active and passive. Another characteristic of children is almost seen as their high level of activity and tendency to be curious. The last, children can hold their attention for only about 15 to 20 minutes. This is very different from adults who can focus on learning for hours. That is why young learner teachers must create a pleasant learning atmosphere.

The previous research of the use of instructional media has been done before by several researchers. The first is Puspitarini \& Hanif (2019) entitled Using Learning Media to Increase Learning Motivation in Elementary School. The results of this research found that in learning process the teachers using lecture methods and learning resources used were books. The use of lecture method in the learning process does not attract students so students do not understand the material presented and student learning motivation is decreased. Besides, Learning resources are always used is a book, where the delivery of all material comes from the book so that students quickly get bored and difficult to understand the material. The second is Zamzami, (2019) Entitled a Study of the Teaching English for Young Learners at Islamic Elementary 
School Islamiyah Malang. The result of this research found that in teaching English, teachers often use several media, namely, audio media, visual media, and audiovisual media. The teacher uses media that is appropriate for the material to be able to attract the attention of students while studying. The last is Miaz, Kenedi, Monafajri, \& Helsa, (2019) entitled Educative Learning Media for Elementary School Student. The result of this research show that the development of android-based educational leraning media for elementary student is valid, practical and effective.

From the previous research above, this study only focus to find how the media were used in the English teaching process in elementary school and the preparations made by the teacher before using media in classroom.

\section{METHOD}

This research used descriptive qualitative as a method. According to Sugiyono (2017) as cited in Cahyati et al., (2019), Qualitative research method is a research method based on the philosophy of positivism, used to examine natural object conditions (as opposed to experiments) where the researcher is the key instrument, purposive and snowball sampling, data collection techniques, data analysis inductive/qualitative, and the results of qualitative research emphasize more meaning than generalization. Its mean descriptive qualitative explains the results of research by describing and explaining the situation or something by the reality that happened.

This Research was conducted at elementary school in Bandung, West Java. The participants in this study were 30 grade 3 elementary school students and an English teacher. In the process of collecting data this study uses three types of instruments, namely observation, interview and document analysis. Observation is used to find out how media is implemented in the classroom by the teacher. The interview is used to find out how the preparation process for making instructional media by the teacher. While the Analysis document is used to determine the lesson plan used, whether the material presented is in accordance with the objectives of the lesson.

\section{RESULTS AND DISCUSSION}

\section{Results}

The result of this study found that in the process of learning English at elementary school in third grade, the teacher used several media. The author made an observation two time to class. The first observation result, the teacher used realia as a media with material about food. The teacher brings a cake from home, when learning begins the teacher mentions the taste of cake in English which is then repeated by all students. teacher utilize realia to make student directly see the object. The second result, teacher used coursebook as a media. The material discussed is still about food. In learning process the teacher ask student to read a vocabulary about food like a taste of food and name of food. After that, the teacher asked student to fill the questions in coursebook. Coursebook has provided by school so every student has a coursebook. Both of this media, do not required preparation because have been already provided at school. The utilize of media depends on the material, the media will be chosen according to the material of the teaching material. Such as, using video to train on students' speaking and listening skills. Picture is to increase children's knowledge about vocabulary. While books are used to practice student's reading and writing skills. All this preparation process is usually done at home, or the day before teaching process. 


\section{Discussion}

\section{Preparation of teachers in the use of instructional media}

This study uses interviews as an instrument to determine the preparation made by the teacher. The result of interview show that the preparation the instructional media is choose instructional media that suitable with the material and mastering the material. The teacher choose instructional media appropriate with material to be studied, for example using video to train on students' speaking and listening skills. Picture is to increase children's knowledge about vocabulary. Course books are used to practice student's reading and writing skills. Meanwhile realia digunakan agar siswa bisa secara langsung melihat objek. The teacher makes media at home and does it one night before the teaching process. The teacher does not feel difficulties because the media used are very easy to find and made. Such as video and pictures, the teachers can get it easily at home by printing images and download video from internet. While course book has been provided by the school so do not require preparation. The last media preparation, namely realia, in the preparation of this media the teacher does not find difficulties because realia objects are already found around the class or asks students to bring realia media from home.

Besides chosee the instructional media, the teacher must also master the material, thus all the material that has been prepared by the teacher can be conveyed clearly and easily understood by young learner. The teacher usually reads and understands the material to be taught a day before the learning process to achieves the goals of learning. This is achieved at the time of observation, the teacher conveys the material clearly, students as recipients of the material can easily understand it. Students respond to every teacher's command correctly. In addition to preparation of media, the teacher does not feel difficulties because uses media easily found, and using very inexpensive media. Also, all media can be used easily by the teacher, but can attract students' attention.

\section{Utilize the instructional media in the classroom by the teacher}

To find out the instructional media used by the teacher during the learning process, the writer makes observations into the classroom and interview the teacher. The teachers used instructional media depends on the learning material. From the three kind of media described by Kasbolah the teachers use two kind of media namely visual media and audio-visual media. Namely, course books, realia, video and pictures.

The first media introduced to the student is realia, where student taught about food. The students who where taught usually young leraner age 8 to 9 years old. In line with the theory of Cahyati et al. (2019) that young learners have tendency to be curious and thus they always have interest in new things. Through this media, students can directly see the object and equate the perception of the material discussed by the teacher. The realia used is from the real shapes and thus easier to find to be thaught to the students. According to the teacher, not all materials can use realia, this media must be adapted to the material and the level of difficulty. That is, if the material discussed is about items that are often found, it can use realia. But if the material is about objects that are difficult to found, it will be difficult to use realia.

The second media is course book. The material taught still about food. As a part of educational systems, textbooks and teaching materials are of paramount significance (Rachmijati \& Cahyati, 2018). Course book are used as the main source of the learning process. It contains material and exercises for students. In learning process, the teacher uses this media to teach 
material related to reading and writing English. Almost every meeting, the teacher uses books for learning activity. According to Cahyati et al., (2019), young learners are their tendency to be active, its mean through this media teachers can find which students prefer to be active and which students prefer to be quiet. Coursebook is used to learn to read and write that requires students to sit on the bench so it is easy to distinguish between students who are active and not.

The third media namely video. The video shown is still themed about food. Video is used to train the way students speaking and listening, through video students can hear how to pronounce correct English sentence. Besides that, students also become entertained by watching videos. The disadvantage of using this video is that students no longer focus on the lesson but rather focus on watching the video, so the teacher needs to control the activities of students while watching the video. The last media is picture, therefore it can be seen by the whole students thus the teacher printed the picture in a larger size. The selected picture also uses bright colors. The printed image is also accompanied by a description of the picture, for example a picture of a apple with the words apple, this paper serves to add to student vocabulary. Indirectly students can read the sentence in the picture so it can add student's vocabulary.

The use of instructional media such as videos about food and pictures in young learner classes is expected to be able to attract the attention of all students, by displaying interesting videos and colorful images that can reduce student boredom while studying. This is in line with the theory of Cahyati et al., (2019) that students aged 8-9 years are very easily bored and only focus on the first 15 minutes. Therefore, videos and pictures can be used as learning media for material related to speaking or listening skill.

Seen at the time of observation, the teacher utilized media very well, with the use of media in classroom students become more interested in learning and more focused attention on the teacher. It is relevant with teori dari Sanaky (2009) as cited by Puspitarini \& Hanif (2019) that there are several benefits of using instructional media, such as by using learning media, the learning process will be more interesting, (2) can clarify learning materials, so that student can easily understand the material and enable student to master the learning objectives. The teachers often use several types of media in the learning process. The different media used aims to make students not get bored in the lesson, and also adjust to other students who don't like the same media.

\section{CONCLUSION}

This study analyzes how the preparation of the teacher in teaching English to young learner and the teacher utilize the media in the classroom. The most important preparation for teacher is to choose instructional media in accordance with the material and master the material. Examples include using video media to practice speaking and listening, pictures to increase student vocabulary, books to practice reading and writing, while realia is intended so that students can directly see objects. The way teachers utilize the learning media depends on the learning material. In this study, the authors found four instructional media used in class, namely course books, videos, realia, and pictures. Besides using a variety of media the teacher also creates a pleasant classroom atmosphere, for example by singing and coloring. The ability of teachers to manage time and learning activities in class, reduce boredom and the level of learning difficulties, is evidenced by the enthusiasm of each student who follows the lesson from the beginning to the closing activity. The teacher conveys the material in a simple but still in accordance with the learning objectives. According to the author, the way the teacher prepares the material for one day before learning is considered sufficient, because the material for grade 
3 to elementary school is still about simple vocabulary. It's just to make instructional media can be improved by making something even more interesting.

\section{ACKNOWLEDGMENTS}

We thank the family, parents, friends and lecturers who have given us support both morally and materially, so that we can complete and publish our article.

\section{REFERENCES}

Cahyati, S. S., Parmawati, A., \& Atmawidjaja, N. S. (2019). Optimizing English Teaching And Learning Process To Young Learners ( A Case Study In Cimahi ). Journal Of Educational Experts (Jee), 2(2), 107-114.

Farida, D., Isrina, H. D., \& Apsari, Y. (2019). The Implementation Of Flash Cards To Improve Students'vocabulary Mastery. Project (Professional Journal Of English Education), 2(3), 352-357.

Isry Laila Syathroh, Bachrudin Musthafa, P. P. (2019). Providing Teaching Resources For Young Learner Classes: Best Practices In Efl Context Isry Laila Syathroh*. Elt In Focus, 2(2). Https://Doi.Org/10.35706/Eltinfc.V2i2.3054

Lisa, H. (2019). The Effectiveness Of Flashcards On The Motivation To Increase English Vocabulary Among The Fourth Elementary School. Journal Of Apllied Linguistic And Literature (Joall), 4(1), 43-53. Https://Doi.Org/10.33369/Joall.V4i1.6852

Miaz, Y., Kenedi, A. K., Monafajri, W. S., \& Helsa, Y. (2019). Educative Learning Media For Elementary School Students. Advanced In Social Science, Education And Humanities Research, 382, 722-727.

Puspitarini Dwi Yanuari, And H. M. (2019). Using Learning Media To Increase Learning Motivation In Elementary School. Anatolian Journal Of Education, 4(2), 53-60.

Puyada, D., Ganefri, G., Ambiyar, A., Wulansari, R. E., \& Hayadi, B. H. (2018). Effectiveness Of Interactive Instructional Media On Electrical Circuits. International Journal Of Engineering \& Technology, 7, 220-223.

Rachmijati, C., \& Cahyati, S. S. (2018). Gender Representation In Textbook Bahasa Inggris Grade X. Eltin Journal, 6(2), 59-69.

Saud, I. W., \& Rahman, Y. (2019). Integrating Local Cultural Animated Video As A Media In English Language Teaching To Promote Students ' Character In Gorontalo Elementary Schools. English Teaching Journal (Eternal), 10(2), 15-23.

Utami, M. S., Fauziati, E., \& Rochsantiningsih, D. (2019). English Instructional Materials For The Integrated Islamic Elementary School ( Sdit ). Journal Of Teaching\& Learning English Iin Multicultural Contexts (Tlmec), 3(2), 74-80.

Zamzami, M. A. (2019). A Study Of The Teaching English For Young Learners At Islamic Elementary School Islamiyah Malang. Jurnal Akademika, 1, 77-98. 